\title{
Teaching \& Learning Guide for: Shaftesbury on Persons, Personal Identity and Character Development
}

\author{
Ruth Boeker \\ University College Dublin \\ Penultimate Version \\ Published in Philosophy Compass 15:8 (2020): e12698 \\ https://doi.org/10.1111/phc3.12698
}

This guide accompanies the following article

Ruth Boeker, 'Shaftesbury on Persons, Personal Identity, and Character Development.'

Philosophy Compass 13/1 (2018): e12471, 10.1111/phc3.12471

\section{Author's Introduction}

Eighteenth-century philosophers engage in lively debates about persons and personal identity. Many of these debates were prompted by John Locke's publication of his chapter "Of Identity and Diversity" (II.xxvii), which he added to the second edition of his An Essay concerning Human Understanding in 1694. Locke's thinking about persons and personal identity is innovative in many respects. For instance, Locke argues that the idea of a person should be distinguished from the ideas of a human being and a substance. For Locke, personal identity consists in sameness of consciousness and persons rather than human beings or substances are held accountable for their actions and continue to exist in the afterlife. Locke's novel views were widely discussed soon after their publication. Although Locke had some defenders such as Catharine Trotter Cockburn, he also had many critics. Many of his critics attack his position on metaphysical and/or religious grounds. However, Locke's view can also be questioned on moral grounds. Anthony Ashley Cooper, the Third Earl of Shaftesbury (hereafter "Shaftesbury"), offers an alternative approach to persons and personal identity, which is shaped by his virtue-ethical moral views and his belief that philosophy should be practical. He shifts the focus of traditional metaphysical debates about personal identity towards practical questions of selfimprovement. His approach to persons and personal identity has a developmental dimension, which focuses on personal growth and improvement of character. Personal development is a gradual process and a practical project of life. Including Shaftesbury's philosophy in a course on philosophical debates about persons and personal identity has the advantage that it can lead to interesting discussion concerning the role of ethics and metaphysics in theories of persons and personal identity. For instance, one can ask in what sense approaches to persons and personal identity can or should be normative, ethical or practical. 


\section{Author Recommends:}

Boeker, Ruth (forthcoming). Locke on Persons and Personal Identity. Oxford: Oxford University Press.

Chapter 11 focuses on Shaftesbury's and Hume's responses to Locke's account of persons and personal identity. Both philosophers generally share Locke's metaphysically agnostic views, but disagree with Locke on moral and religious grounds. Contrasting their moral and religious views brings to light how their different moral and religious views shape their thinking about persons and personal identity and why Shaftesbury and Hume develop views that differ from Locke's position.

Boeker, Ruth (2019). 'Shaftesbury on Liberty and Self-Mastery.' International Journal of Philosophical Studies 27 (5): 731-752. DOI:

https://doi.org/10.1080/09672559.2019.1674362

This paper argues that Shaftesbury's thinking about liberty is best understood in terms of selfmastery and thus a version of positive liberty. It claims that self-mastery, as Shaftesbury understands it, is a developmental process, and shows that this interpretation is more promising than other attempts to situate Shaftesbury's view within debates among compatibilists and incompatibilists.

Gill, Michael B. (2016). 'Love of Humanity in Shaftesbury's Moralists.' British Journal for the History of Philosophy 24(6): 1117-1135. DOI:

https://doi.org/10.1080/09608788.2016.1198303

This paper offers a close examination of Shaftesbury's account of virtue in his work The Moralists. Shaftesbury regards virtue in its full perfection as love of all of humanity, but also raises doubt whether humans are capable of such abstract love of humanity. This tension whether humans are capable to act in the way that virtue requires arises, Gill argues, because Shaftesbury is a rationalist about the content of morality and a sentimentalist about moral motivation.

Jaffro, Laurent (2008). 'Shaftesbury on the "Natural Secretion" and Philosophical Personae.' Intellectual History Review 18(3): 349-359. DOI:

https://doi.org/10.1080/17496970802319235

This paper focuses on Shaftesbury's views of self-fashioning and argues that his concept of a philosophical persona, which has a private and a public side, builds on Stoic philosophy. Jaffro draws particular attention to Shaftesbury's unpublished personal notebooks, titled Askêmata (meaning exercises). In Askêmata Shaftesbury introduces a distinction between the natural self, which is in charge of self-government, and the economical self, which administers relations with others. Both selves have a normative dimension, since the natural self is tasked to consider how one ought to govern oneself and the economical self how one ought to manage one's sociable part and outward character.

Jaffro, Laurent (2014). 'Cyrus' Strategy: Shaftesbury on Human Frailty and the Will.' In Patrick Müller (Ed.), New Ages, New Opinions: Shaftesbury in his World and Today (153-165). Frankfurt am Main: Peter Lang.

This paper focuses on Shaftesbury's conception of the will. Jaffro analyses Shaftesbury's different conceptions of self-control, namely naïve beliefs that one can control one's passions, an avoidance strategy, and Stoic self-discourse, or soliloquy. Since Shaftesbury regards constancy of the will as closely intertwined with questions of personal identity, Jaffro argues that Shaftesbury directly connects metaphysical questions of personal identity with normative identity.

Purviance, Susan M. (2004). 'Shaftesbury on Self as a Practice.' Journal of Scottish Philosophy 2(2): 154-163. DOI: https://doi.org/10.3366/jsp.2004.2.2.154 
This paper emphasizes that Shaftesbury's approach to self is practical or ethical, rather than theoretical or metaphysical and shows how his view differs from Hume's and Reid's views. According to Purviance, Shaftesbury's account of self is a practical project of life that aims at integrity and unity is constituted by these attempts to reach integrity.

Thiel, Udo (2011). The Early Modern Subject: Self-consciousness and Personal Identity from Descartes to Hume. Oxford: Oxford University Press.

This book includes a section on Shaftesbury's criticism of Locke's account of personal identity (section 5.2.5), discusses Shaftesbury's contribution to debates about self and personal identity (section 7.2), and comments on Hume's reference to Shaftesbury in Treatise 1.4.6 (section 12.3). Thiel considers Shaftesbury's approach to the self in the context of Shaftesbury's discussion of the self of the universe, which he also calls a universal mind. Thiel regards Shaftesbury's account of the self as an immaterial substance view and argues that Shaftesbury's philosophy is not just ethical, but also metaphysical.

Winkler, Kenneth P. (2000) “"All is Revolution in Us": Personal Identity in Shaftesbury and Hume.' Hume Studies 26(1): 3-40. DOI: http://dx.doi.org/10.1353/hms.2011.0311 This paper examines debates and controversies in early modern philosophy of whether the topic of personal identity is metaphysical or ethical and shows with particular focus on Shaftesbury's and Hume's philosophy how philosophical positions shift during this period. Winkler explains how Shaftesbury moves beyond Locke's philosophy and argues that Shaftesbury locates personal identity in the will, rather than the understanding. Since the will can be seen as a seat of active principles, persons for Shaftesbury play an active role in their constitution.

Yaffe, Gideon (2002). 'Earl of Shaftesbury.' In Steven Nadler (Ed.), A Companion to Early Modern Philosophy (425-436). Malden, MA: Blackwell.

This chapter offers a helpful introduction to Shaftesbury's life, major works, and his philosophical contributions to British moral philosophy and aesthetics.

\section{Online Materials:}

Stanford Encyclopedia of Philosophy Entry on Shaftesbury: https://plato.stanford.edu/entries/shaftesbury/

Internet Encyclopedia of Philosophy Entry on Shaftesbury: https://www.iep.utm.edu/shaftes/

Shaftesbury Project:

https://www.angam.phil.fau.de/fields/enst/lit/shaftesbury/

\section{Sample Syllabus:}

The following is a partial sample syllabus for a graduate course on debates about personal identity in early modern philosophy. The course can also be taught as an advanced undergraduate course, though depending on student level and ability it may make sense to reduce the assigned and suggested further readings. Since many students will have encountered concepts such as identity or personal identity in a variety of different contexts, I find it helpful to begin the course with systematic reflections on the different philosophical questions concerning identity and personal identity, paying particular attention to metaphysical and ethical issues. 
The following partial syllabus begins with Locke, but other historical authors can be covered during early weeks. For instance, one can include a week or two on Descartes's understanding of mind and body and Locke's criticism of Cartesian views and examine the historical and philosophical context in which Locke developed his view about persons and personal identity. Many more seventeenth and eighteenth-century thinkers contribute to the philosophical debates about persons and personal identity than can be included in a single course. My course aims to engage both with the metaphysical and the ethical debates concerning personal identity. Thus, I selected authors who make interesting contributions to the metaphysics of personal identity (e.g. Locke, Leibniz, Butler, Reid, Cockburn, Clarke, Collins, Hume) and ethical questions concerning personal identity (e.g. Locke, Molyneux, Leibniz, Law, Shaftesbury, Hume). It is possible to end the course by turning to the reception and development of the early modern debates about personal identity in twentieth and twentyfirst century philosophy.

\section{Week 1: Locke on Identity}

How does Locke approach questions of identity over time? In what, if any, sense does his account of identity over time depend on the kind of being under consideration? How do relative identity theories differ from coincidence interpretations? Is Locke committed to either type of interpretation?

\section{Reading:}

Locke, John (1975 [1690]). An Essay concerning Human Understanding. Edited by Peter H. Nidditch. Oxford: Clarendon Press, Book II, chapter xxvii (with focus on Locke's general approach to identity in the first half of the chapter)

Chappell, Vere (1989). 'Locke and Relative Identity.' History of Philosophy Quarterly 6: 6983.

Suggested further reading:

'*' denotes highly recommended

Boeker, Ruth (forthcoming). Locke on Persons and Personal Identity. Oxford: Oxford University Press, chapters 2-3.

Gordon-Roth, Jessica (2015). 'Locke's Place-Time-Kind Principle.' Philosophy Compass 10(4): 264-274.

Hoffman, Joshua (1980). 'Locke on Whether a Thing Can Have Two Beginnings of Existence.' Ratio 22(2): 106-111.

Kaufman, Dan (2007). 'Locke on Individuation and the Corpuscular Basis of Kinds.' Philosophy and Phenomenological Research 75(3): 499-534.

Rickless, Samuel C. (2014). Locke. Chichester: Wiley-Blackwell, ch. 8.

*Stuart, Matthew (2013). Locke's Metaphysics. Oxford: Clarendon Press, 2013, ch. 7.

\section{Week 2: Locke on Persons and Personal Identity}

How does Locke characterize a person? What does Locke mean when he states that 'person' is a forensic term? How does Locke account for personal identity over time? What role do questions of moral accountability play in Locke's theory? How do Locke's and Leibniz's views about identity, persons, and personal identity differ? Do you find Locke's or Leibniz's 
view more convincing? How could Locke respond to Leibniz's claim that the testimony of others could fill the gaps in one's recollection? What are the strengths and weaknesses of Law's reading of Locke?

Reading:

Locke, Essay, II.xxvii.

Selections from Locke's correspondence with William Molyneux. In John Locke (19761989), The Correspondence of John Locke. Edited by E. S. de Beer, 8 volumes. Oxford: Clarendon Press, letter no 1685, 4:767-768, letter no 1693, 4:784-787.

Leibniz, Gottfried (1996). New Essays on Human Understanding. Edited by Peter Remnant and Jonathan Bennett. Cambridge: Cambridge University Press, Book II, chapter xxvii.

Law, Edmund (1824 [1769]). A Defence of Mr. Locke's Account of Personal Identity. In John Locke, The Works of John Locke. $12^{\text {th }}$ ed., 9 volumes. London: Printed for C. and J. Rivington et al, 2:301-320. Accessible electronically via http://oll.libertyfund.org/index.php?option=com_staticxt\&staticfile=show.php\%3Ftitle=7 $62 \&$ Itemid $=28$

Suggested further reading:

Boeker, Ruth (forthcoming). Locke on Persons and Personal Identity. Oxford: Oxford University Press, ch. 4.

Boeker, Ruth (2014). 'The Moral Dimension in Locke's Account of Persons and Personal Identity.' History of Philosophy Quarterly 31(3): 229-247.

Curley, Edwin (1982). 'Leibniz and Locke and the Problem of Personal Identity.' In Michael Hooker (Ed.), Leibniz: Critical and Interpretive Essays (303-326). Minneapolis: University of Minnesota Press.

Gordon-Roth, Jessica (2015). 'Locke on the Ontology of Persons.' Southern Journal of Philosophy 53(1): 97-125.

LoLordo, Antonia (2012). Locke's Moral Man. Oxford: Oxford University Press, ch. 2.

Mackie, J. L. (1976). Problems from Locke. Oxford: Oxford University Press, ch. 6.

Spector, Jessica (2008). 'The Grounds of Moral Agency: Locke's Account of Personal Identity.' Journal of Moral Philosophy 5(2): 256-281.

Tabb, Kathryn (2018). 'Madness as Method: Locke's Thought Experiments about Personal.' British Journal for the History of Philosophy 26(5): 871-889.

Weinberg, Shelley (2011). 'Locke on Personal Identity.' Philosophy Compass 6(6): 398-407.

\section{Week 3: Common Objections: Circularity and Transitivity}

Is Locke's account of personal identity circular? If so, in what sense? How could Locke respond to the circularity worry? Is the transitivity objection a serious problem for Locke's theory? Recently Matthew Stuart (and Galen Strawson) have argued that Locke's theory is non-transitive. What are the strength and weaknesses of non-transitive interpretations?

Reading:

Butler, Joseph (1897 [1736]). 'Of Personal Identity.' In Joseph Butler, The Works of Joseph Butler. Edited by W. E. Gladstone, 2 volumes (1:317-325). Oxford: Clarendon Press. Reprinted in John Perry (Ed.) (2008). Personal Identity. Berkeley: University of California Press ( $\left.2^{\text {nd }} e d.\right), 99-105$. 
Reid, Thomas (2002 [1785]). 'Of Mr. Locke's Account of Our Personal Identity.' In Thomas Reid, Essays on the Intellectual Power of Man. Edited by Derek R. Brookes. Edinburgh" Edinburgh University Press, Essay III, chapter vi, 275-279. Reprinted in Perry (Ed.), Personal Identity, 113-118.

Stuart, Matthew (2013). Locke's Metaphysics. Oxford: Clarendon Press, ch. 8.

Suggested further reading:

Boeker, Ruth (forthcoming). Locke on Persons and Personal Identity. Oxford: Oxford University Press, chapters 6 and 8.

Garrett, Don (2003). 'Locke on Personal Identity, Consciousness, and "Fatal Error".' Philosophical Topics 31(1/2): 95-125.

Gordon-Roth, Jessica (2019). 'Tracing Reid's “Brave Officer” Objection Back to Berkeleyand Beyond.' Berkeley Studies 28: 3-22.

Strawson, Galen (2011). Locke on Personal Identity. Princeton: Princeton University Press, chapters $10-12$.

*Thiel, Udo (2011). The Early Modern Subject: Self-consciousness and Personal Identity from Descartes o Hume. Oxford: Oxford University Press, ch. 6.

\section{Week 4: On the Immateriality and Immortality of the Soul}

Several of Locke's early critics worry that his view undermines the immateriality and immortality of the soul. Are there any good arguments for the view that persons are immaterial substances? Does immortality presuppose immateriality? Catharine Trotter Cockburn presents clever arguments to defend Locke's view against anonymously published objections. How does Cockburn argue against the view that the soul always thinks? How does she defend the possibility of thinking matter? Samuel Clarke and Anthony Collins discuss the possibility of thinking matter in their correspondence. Clarke endorses immaterialism and rejects the possibility of thinking matter, while Collins believes that it is possible that matter can think. Which view do you find more convincing, and why?

Reading:

Cockburn, Catharine Trotter (2006 [1702]). A Defence of Mr. Locke's Essay of Human Understanding. In Catharine Trotter Cockburn, Philosophical Writings. Edited by Patricia Sheridan. Peterborough, ON: Broadview Press, 53-63.

Uzgalis, William (2008). 'Selections from the Clarke-Collins Correspondence.' In John Perry (Ed.). Personal Identity (283-314). Berkeley: University of California Press ( $2^{\text {nd }}$ ed.).

Suggested further reading:

Boeker, Ruth (forthcoming). 'Locke on Being Self to My Self.' In Patricia Kitcher (Ed.), The Self: A History. New York: Oxford University Press, especially section 5.

Boeker, Ruth (forthcoming). Locke on Persons and Personal Identity. Oxford: Oxford University Press, ch. 10.

Ducharme, Howard (1986). 'Personal Identity in Samuel Clarke.' Journal of the History of Philosophy 24(3): 359-383.

*Gordon-Roth, Jessica (2015). 'Catharine Trotter Cockburn's Defence of Locke.' The Monist 98(1): 64-76. 
Hume, David (2007 [1739-40]). A Treatise of Human Nature. Edited by David Fate Norton and Mary J. Norton. Oxford: Clarendon Press, 1.4.5. Accessible electronically via https://davidhume.org/texts/t/1/4/5

Hume, David (1994). 'Of the Immortality of the Soul.' In David Hume, Essays Moral, Political, and Literary. Edited by Eugene F. Miller. Indianapolis: Liberty Fund, 590-598. Accessible electronically via https://davidhume.org/texts/is/

Lähteenmäki, Vili (2014). 'Anthony Collins and the Status of Consciousness.' Vivarium 52(3-4): 315-332.

*Rozemond, Marleen (2009). 'Can Matter Think? The Mind-Body Problem in the ClarkeCollins Correspondence.' In Jon Miller (Ed.), Topics in Early Modern Philosophy of Mind (171-192). Dordrecht: Springer.

Thiel, Udo (1998). 'Locke and the Eighteenth-Century Materialist Conceptions of Personal Identity.' The Locke Newsletter 29: 59-83. Reprinted in Udo Thiel (Ed.). Locke: Metaphysics and Epistemology. Adlershot: Ashgate, 2002.

Thomas, Emily (2015). 'Catharine Cockburn on Unthinking Immaterial Substance: Souls, Space, and Related Matters.' Philosophy Compass 10(4): 255-263.

Uzgalis, William (2008). 'Locke and Collins, Clarke and Butler, on Successive Persons.' In John Perry (Ed.), Personal Identity (315-326). Berkeley: University of California Press ( $2^{\text {nd }}$ ed.).

\section{Week 5: Shaftesbury}

How does Shaftesbury approach questions of self and personal identity? How does Shaftesbury criticize bodily and psychological accounts of personal identity? What is his positive approach to self and personal identity? What role does, can, or should character development or self-improvement play in theories of selfhood and personal identity? Too what extent is Shaftesbury's view normative, ethical or practical? Too what extent is his view metaphysical?

Reading:

Shaftesbury, Antony Ashley Cooper, Third Earl of (2001 [1711]). Characteristicks of Men Manners, Opinions, Times. Edited by Douglas Den Uyl, 3 volumes. Indianapolis: Liberty Fund. Accessible electronically via http://oll.libertyfund.org/titles/shaftesburycharacteristicks-of-men-manners-opinions-times-3-vols

[Vol. 1] Soliloquy, or Advice to an Author Part I, Sect. 1-2, 1:97-118; Part III, Sect. 1, $1: 173-187$.

[Vol. 2] The Moralists, a Philosophical Rhapsodie, Part II, Sect. 1-2, 2:125-146; Part III, Sect. 1, 2:191-205.

[Vol. 3] Miscellany IV, chapter 1, 3:116-128.

Suggested further reading:

*Boeker, Ruth (2018). 'Shaftesbury on Persons, Personal Identity and Character Development.' Philosophy Compass 13(1): e12471.

Boeker, Ruth (forthcoming). Locke on Persons and Personal Identity. Oxford: Oxford University Press, ch. 11.

Gill, Michael (2017). 'Lord Shaftesbury [Anthony Ashley Cooper, 3rd Earl of Shaftesbury].' In Edward N. Zalta (Ed.), The Stanford Encyclopedia of Philosophy (Winter 2017 ed.), http://plato.stanford.edu/entries/shaftesbury/ 
Jaffro, Laurent (2008). 'Shaftesbury on the "Natural Secretion" and Philosophical Personae.' Intellectual History Review 18(3): 349-359.

Jaffro, Laurent (2014). 'Cyrus's Strategy: Shaftesbury on Human Frailty and the Will.' In Patrick Müller (Ed.), New Ages, New Opinions: Shaftesbury in his World and Today (153165). Frankfurt am Main: Peter Lang.

Purviance, Susan M. (2004). 'Shaftesbury on Self as a Practice.' Journal of Scottish Philosophy 2(2): $155-163$.

Winkler, Kenneth P. (2000). “"All is Revolution in Us”: Personal Identity in Shaftesbury and Hume.' Hume Studies 26(1): 3-40.

\section{Week 6: Hume on Personal Identity as regards our Thought and Imagination}

What are Hume's negative claims about the self? What are Hume's positive claims about the self? How does Hume explain our belief in personal identity over time? Is Hume's philosophical project metaphysical, psychological, or sceptical? What exactly is the problem that Hume identifies in the Appendix? How does Hume's view differ from Locke's? How could Locke respond to Hume?

Reading:

Hume, David (2007 [1739-40]). A Treatise of Human Nature. Edited by David Fate Norton and Mary J. Norton. Oxford: Clarendon Press, 1.4.6 and Appendix. Accessible electronically via https://davidhume.org/texts/t/

Suggested further reading:

Baxter, Donald L. M. (2008). Hume's Difficulty: Time and Identity in the Treatise. New York: Routledge.

Boeker, Ruth (forthcoming). Locke on Persons and Personal Identity. Oxford: Oxford University Press, ch. 11.

Cottrell, Jonathan (2015). 'Minds, Composition, and Hume's Skepticism in the Appendix.' Philosophical Review 124(4): 533-569.

*Garrett, Don (1997). Cognition and Commitment in Hume's Philosophy. New York: Oxford University Press, ch. 8.

Hume, Treatise, 1.4.2.

*McIntyre, Jane L. (2009). 'Hume and the Problem of Personal Identity.' In David Fate Norton and Jacqueline Taylor (Eds.), The Cambridge Companion to Hume (177-208), Cambridge: Cambridge University Press.

Strawson, Galen. The Evident Connexion: Hume on Personal Identity. Oxford: Oxford University Press.

Thiel, Udo (2011). The Early Modern Subject: Self-consciousness and Personal Identity from Descartes to Hume. Oxford: Oxford University Press, chapters 12 and 13.

\section{Week 7: Hume on Personal Identity as it regards our Passions and Concern in Ourselves}

What is the relation between Hume's account of self in Book 1 and in Book 2 of the Treatise? Has Hume changed his view? What role do self and other people play in Hume's account of the indirect passions, namely pride and humility, and love and hatred? In what way do other 
people contribute to the constitution of a self? How is a Humean self connected with the past and future?

Reading:

Hume, Treatise, 2.1.1-7, 11 and 2.2.1-5, 9.

Suggested further reading:

Baier, Annette C. (1991). A Progress of Sentiments: Reflections on Hume's Treatise. Cambridge, MA: Harvard University Press, ch. 6.

Boeker, Ruth (2015). 'Locke and Hume on Personal Identity: Moral and Religious Differences.' Hume Studies 41(2): 105-135.

Hume, Treatise, 2.1-2, 3.3.1-3, 3.3.6.

*McIntyre, Jane (1989). 'Personal Identity and the Passions.' Journal of the History of Philosophy 27(4): 545-557.

*Taylor, Jacqueline (2015). 'Sympathy, Self, and Others.' In Cambridge Companion to Hume's Treatise, edited by Donald C. Ainslie and Annemarie Butler (188-205). Cambridge: Cambridge University Press.

Taylor, Jacqueline (2015). Reflecting Subjects: Passion, Sympathy and Society in Hume's Philosophy. Oxford: Oxford University Press.

Wright, John P. Hume's 'A Treatise of Human Nature'. Cambridge: Cambridge University Press, ch. 6.

\section{Focus Questions}

1. How does Shaftesbury criticize psychological accounts of personal identity?

2. Do you find Shaftesbury's criticism of psychological accounts of personal identity convincing? Why, or why not?

3. What is Shaftesbury's own positive approach to persons and personal identity?

4. To what extent is Shaftesbury's approach to persons and personal identity normative, ethical or practical, and to what extent is it metaphysical?

5. Are questions or personal development connected with questions of personal identity? Or are these separate philosophical issues? 